\title{
Clinical, surgical, and radiographic aspects in a white-eared opossum (Didelphis albiventris) with traumatic diaphragmatic hernia
}

\section{Aspectos clínicos, cirúrgicos e radiográficos em um Gambá-de-orelha-branca (Didelphis albiventris) com hérnia diafragmática traumática.}

\author{
Carolina Fucks de Souza (i), Ronaldo José Piccoli (D), Paula Eduarda Quintana ${ }^{1}$ (D), \\ Lettycia Demczuk Thomas ${ }^{1}$ (D), Olicies da Cunha ${ }^{1}$ (D), Flávio Shigueru Jojima ${ }^{(1)}$
}

\begin{abstract}
This is the case of a specimen of Didelphis albiventris with signs of respiratory difficulty after a dog attack. Thoracic radiographic examination revealed pneumothorax, pulmonary contusion, and rib fracture, but no alteration compatible with diaphragmatic hernia was observed. Pneumothorax was reduced and the other alterations were treated. However, clinical manifestations persisted, and thus a contrast-gastrointestinal radiographic study was performed, showing abdominal organs in the thoracic cavity and loss of diaphragmatic line. The surgical approach was instituted, with access to the diaphragm through median laparotomy. Through the diaphragmatic rupture, present in the left antimere, there were herniated liver and gastric portions, intestinal segments, and omentum. After inspection and repositioning of the abdominal organs, the diaphragm raffia was performed with single sutures interrupted with 3-0 Nylon thread. The patient's complete recovery occurred 14 days after the surgical procedure, with remission of clinical manifestations and normality of thoracic images in radiographic studies.
\end{abstract}

KEYWORDS: Marsupial; Trauma; Herniorrhaphy; Medium laparotomy.

RESUMO: Esse é o caso de um espécime de Didelphis albiventris com sinais de dificuldade respiratória após ataque por cão. O exame radiográfico torácico revelou pneumotórax, contusão pulmonar e fratura de costelas, porém nenhuma alteração compatível com hérnia diafragmática foi observada. O pneumotórax foi reduzido e as demais alteraçóes tratadas. Contudo; houve a persistência das manifestações clínicas, e dessa forma um estudo radiográfico gastrointestinal contrastado foi realizado, sendo evidenciados órgãos abdominais na cavidade torácica e perda da linha diafragmática. A abordagem cirúrgica foi instituída, com acesso ao diafragma por meio de laparotomia mediana. Através da ruptura diafragmática, presente no antímero esquerdo, estavam herniadas porçóes hepáticas e gástricas, segmentos intestinais e omento. Após inspeção e reposicionamento dos órgãos abdominais, a rafia do diafragma foi realizada com suturas simples interrompidas com fio Nylon 3-0. A recuperação completa do paciente ocorreu 14 dias após o procedimento cirúrgico, com remissão das manifestaçôes clínicas e normalidade das imagens torácicas nos estudos radiográficos.

PALAVRAS-CHAVE: Marsupial; Trauma; Herniorrafia; Laparotomia mediana.

\section{INTRODUCTION}

The white-eared opossum (Didelphis albiventris) is a species of native wild marsupial that plays an important ecological role in the control of arthropods and small vertebrates, besides being a seed disperser and serving as prey for meso and large predators. In Brazil it is widely distributed, where it is found in areas of preserved vegetation and in anthropic environments, which is why conflicts with domestic animals are frequent (OLIVEIRA et al., 2010).

Diaphragmatic hernia is characterized by migration of abdominal organs into the thoracic cavity through continuity solutions in the diaphragm. In addition to the congenital etiology, with alterations during the development phase of the diaphragm, this condition may result from traumatic 
events (BESALTI et al., 2011; HUNT; JOHNSON, 2018; WORTH; MACHON, 2005).

The main clinical manifestations of diaphragmatic hernias include respiratory signs, such as dyspnea, tachypnea and muffling of cardiopulmonary sounds, in addition to those inherent to the herniated organs (BESALTI et al., 2011; COPAT et al., 2017; OZER et al., 2007). However, asymptomatic, or nonspecific manifestations are reported (MOTTA et al., 2012).

The diagnosis of diaphragmatic hernia is performed based on the clinical manifestations associated with the presence of abdominal structures in the thoracic cavity, seen in radiographic and ultrasound evaluations (HYUN, 2004). In inconclusive cases, contrasted radiographic studies and videosurgical approaches can be additional diagnostic tools (BECK et al., 2004; WORTH; MACHON, 2005).

The indicated treatment for this condition is the surgical correction of the hernia, with the raphy of the diaphragm (HUNT; JOHNSON, 2018; WORTH; MACHON, 2005). Access to this structure can be performed by median laparotomy, sternotomy, lateral intercostal thoracotomy, or the association of these techniques (BESALTI et al., 2011; OZER et al., 2007). Extensive diaphragmatic defects can be corrected with the use of biological or synthetic implants (ZIMMERMANN et al., 2008).

The occurrence of traumatic diaphragmatic hernia is widely described in veterinary medicine of dogs and cats. However, there are still gaps in addressing this condition in wild animals. Therefore, it is intended to report the clinical manifestations, diagnosis and surgical correction of traumatic diaphragmatic hernia in a specimen of Didelphis albiventris attacked by a dog.

\section{CASUISTICS}

An adult male white-eared opossum (Didelphis albiventris), weighing $1.1 \mathrm{~kg}$, with a free life, was referred for care with a history of trauma by a domestic dog. During the physical examination, the patient presented abnormal posture and movement, with paresis of the pelvic limbs, and depressed state of consciousness. In addition, pale mucous membranes, mild dehydration (5\%), lean body condition score, rectal temperature of $33.2^{\circ} \mathrm{C}$ (reference value: $34,04 \pm 1,2^{\circ} \mathrm{C}$ - HARO et al. 2018) and capillary refill time (CRT) of 2 seconds were found. The heart rate was 220 beats per minute (reference value: $144 \pm 38$ beats per minute - HARO et al. 2018) and the respiratory rate was 32 respiratory movements per minute (reference value: $26 \pm 8$ movements per minute - HARO et al. 2018), with a superficial restrictive and paradoxical respiratory pattern. Multiple areas of skin continuity solution of varying sizes distributed over the abdominal region of the left antimere were observed. Associated to the perforation areas, an increase in volume and crackling aspect of the subcutaneous was noticed all along the left hemithorax until the ipsilateral abdominal region.

Patient stabilization was achieved by oxygen therapy $(100 \%)$, via face mask, and continuous infusion of lactate ringer solution $(10 \mathrm{~mL} / \mathrm{kg} /$ hour $)$ via intraosseous access in the left femur. Additionally, tramadol hydrochloride $(3 \mathrm{mg} / \mathrm{kg}$, intramuscular [IM]), meloxicam $(0.2 \mathrm{mg} / \mathrm{kg}$, subcutaneous [SC]), enrofloxacin (10 mg/kg, IM), and cleaning and suturing of skin lesions were performed.

Due to the intense dyspnea, with compromised respiratory function, pneumothorax was suspected. Thus, a thoracocentesis relief was performed in the dorsal region of the $7^{\text {th }}$ left intercostal space, with aspiration of approximately $20 \mathrm{~mL}$ of air, which gave a clear improvement of the respiratory pattern at the end of the procedure.

Once stabilized, the patient was submitted to a simple chest and abdomen radiographic examination, with the use of orthogonal projections (Figure 1). In the evaluation of the images, alterations compatible with pulmonary contusion, pneumothorax, $9^{\circ}, 10^{\circ}$ and $11^{\circ}$ fractures in the right ribs, and bilateral subcutaneous emphysema adjacent to the
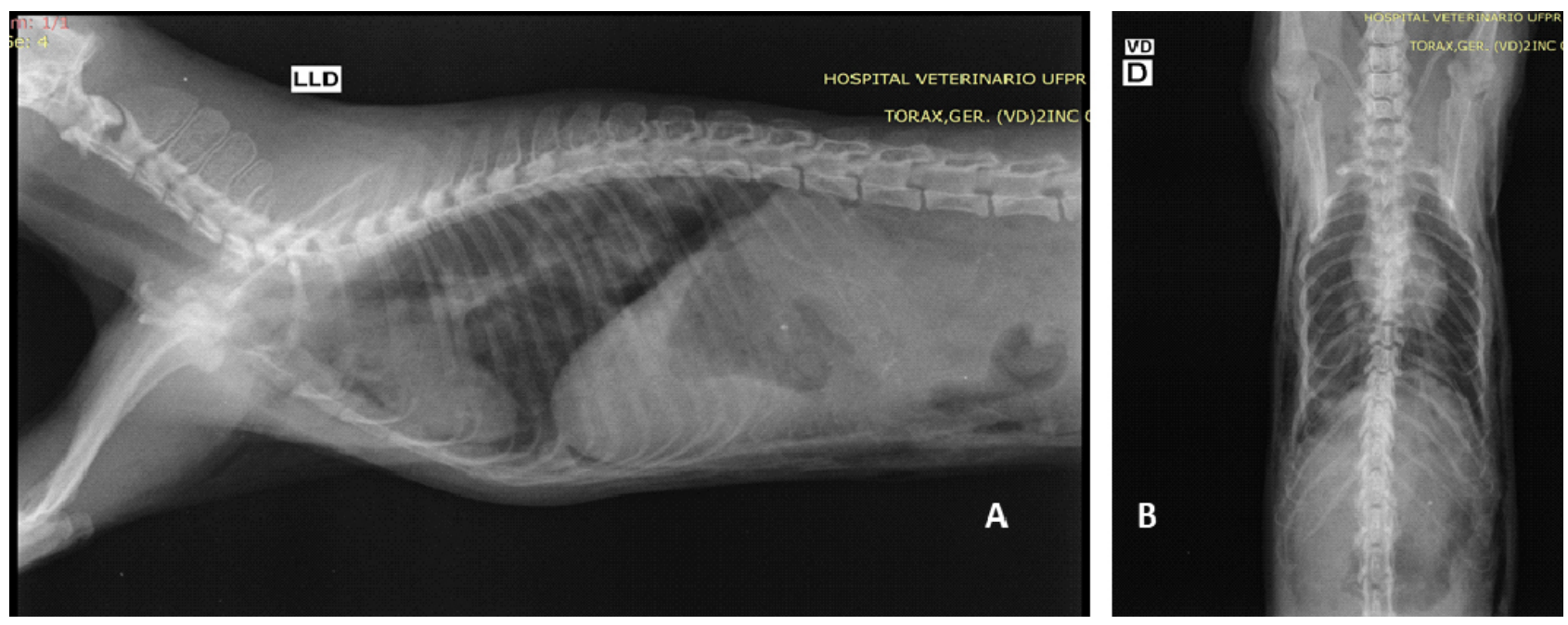

Figure 1. Radiographic image of the chest in a specimen of Didelphis albiventris, in the right lateral (A) and ventrodorsal (B) projections. 
thoracic cavity to the left abdomen were evidenced. In addition, there was a mild pneumoperitoneum and a sixth lumbar vertebra body fracture, without compromising the medullar canal and spinal cord.

At the end of the radiographic evaluation, the patient presented recurrence of clinical respiratory manifestations and a new thoracocentesis relief was performed. After that, the patient was kept at rest with support therapy until the respiratory function and other vital parameters were re-established.

Due to the history of trauma and the persistent clinical respiratory manifestations, diaphragmatic hernia, not evidenced by simple radiographic examination, was suspected. Then, after stabilization, the patient underwent abdominal ultrasound evaluation, where cranial displacement of the liver and intestinal loops was observed at the time of the examination, in addition to changes suggestive of bilateral nephropathy, such as asymmetry and increased renal echogenicity. Diagnostic confirmation of diaphragmatic hernia was performed by gastrointestinal transit examination with barium sulfate $(10 \mathrm{~mL} / \mathrm{kg}$, orally). In the evaluation of the images, after one hour of contrast administration, there was filling of radiopaque tubular structures, compatible with intestinal loops, located in the thoracic cavity (Figure 2).

Prior to the surgical approach, the patient was premedicated with methadone hydrochloride $(0.3 \mathrm{mg} / \mathrm{kg}$, intravenous [IV]) and induced with association of propofol $(5 \mathrm{mg} / \mathrm{kg}, \mathrm{IV})$ and fentanyl $(1.5 \mu \mathrm{g} / \mathrm{kg}, \mathrm{IV})$. Anesthetic maintenance was achieved with the use of isoflurane (2\%), via endotracheal intubation with a $3.0 \mathrm{~mm}$ Murphy probe, and analgesic fentanyl infusion $(10 \mu \mathrm{g} / \mathrm{kg} /$ hour, IV).

The patient was positioned in dorsal decubitus position, and after ample preparation of the operative field, a medial pre-umbilical incision was made, with divulsion of the subcutaneous tissue and access to the abdominal cavity, as described by Hunt and Johnson (2018). During diaphragm inspection, a discontinuity of approximately $6 \mathrm{~cm}$ was in the dorsal aspect of the left antimere. Through the diaphragmatic opening, intestinal segments, the pyloric portion of the stomach, the omentum and the hepatic lobes were projected in the thoracic cavity.

With the aid of moistened gauze in $0.9 \%$ heated $\mathrm{NaCl}$ solution, the organs were pulled, inspected, and repositioned in the abdomen. The diaphragmatic rupture was evaluated, and the possibility of adequate approximation of its edges was verified, dispensing with the use of polypropylene mesh or muscle grafts. Thus, after debridement, the lacerated diaphragmatic edges were sutured in a simple pattern interrupted with 3-0 Nylon thread. Due to the avulsion of the diaphragm of the costal arch, the adjacent rib was incorporated into the suture to increase the sustaining force.

The points were distributed and anchored halfway up the defect for better traction distribution. When the points were closed, the thoracic open air was drained with an $8 \mathrm{~mm}$ transdiaphragmatic probe to re-establish negative pressure. The probe was maintained for additional drainage in the postoperative period (Figura 3).
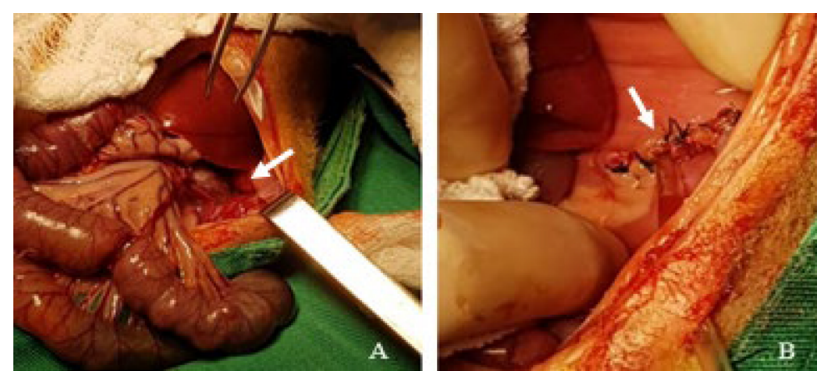

Figure 3. Median laparotomy on a specimen of Didelphis albiventris. (A) Discontinuity in left antimere of the diaphragm (white arrow). (B) Diaphragmatic raphy and $8 \mathrm{~mm}$ transdiaphragmatic probe for thoracic drainage (white arrow).
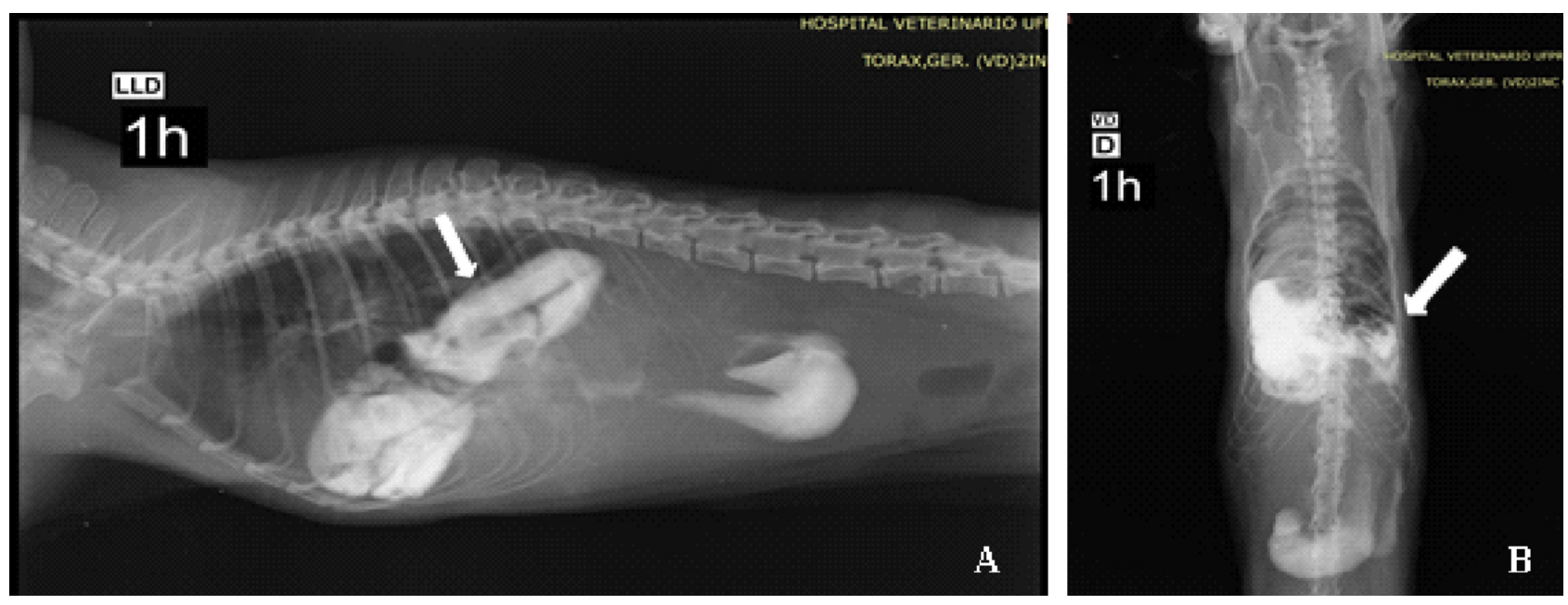

Figure 2. Radiographic image of the chest in a specimen of Didelphis albiventris, at the gastrointestinal transit examination, in the right lateral $(A)$ and ventrodorsal $(B)$ projections. Loss of diaphragm delimitation and presence of contrast filled tubular structures in the thoracic cavity (white arrow) are observed. 
The procedure was finished by raphy in three layers of the abdominal wall, namely: peritoneum and simple muscle fascia, interrupted with 3-0 nylon wire, subcutaneous in zigzag with 3-0 Nylon wire, and skin in Wolf with 3-0 Nylon wire.

During the anesthetic return, the patient was maintained in continuous infusion of lactate ringer solution $(50 \mathrm{~mL} / \mathrm{kg} / \mathrm{day}, \mathrm{IV})$ and in oxygen supplementation by means of face mask after extubation. Tramadol hydrochloride $(3 \mathrm{mg} / \mathrm{kg}$, IM, IDB, for 15 days), meloxicam $(0.2 \mathrm{mg} / \mathrm{kg}$, SC, SID, for 5 days), enrofloxacin (10 mg/kg, IM, IDB, for 15 days) and ranitidine hydrochloride ( $2 \mathrm{mg} / \mathrm{kg}$, SC, IDB, for 15 days) were prescribed. After one hour of the surgical procedure, the patient removed the thoracic drain, thus following constant monitoring for possible pleural and/or pneumothorax effusion, which did not occur.

The day after the surgical procedure, the patient was alert and with normal breathing pattern, but with the presence of slight noises in the pulmonary auscultation. Defecation and normal urination, voluntary ingestion of small amounts of pasty food and permanence at rest were observed. In the control radiographic evaluation, with orthogonal projections of the thoracic region, signs of pulmonary hyperinflation, secondary to recent herniorrhaphy, were no longer observed.

At 14 days postoperatively, the patient was in a stable clinical condition, active, with good healing of the surgical wound and no signs of recurrence. Thus, it was transferred to a rehabilitation facility, where it was kept for another 38 days, period in which the identification of the individual (microchipping) and complementary exams were performed, to follow up the case. After 53 days of the surgical procedure, the patient was released into its habitat with the consent of the responsible environmental agency.

\section{DISCUSSION}

Diaphragmatic hernia of traumatic origin is often diagnosed in dogs and cats (BESALTI et al., 2011; LEGALLET; MANKIN; SELMIC, 2017). The patient in this report presented diaphragmatic hernia resulting from trauma after a dog attack. This condition can also be a result of car accidents, falls and kicks (COPAT et al., 2017; GIBSON; BRISSON; SEARS et al., 2005; OZER et al., 2007).

Diaphragmatic ruptures are usually observed in the muscle portions of this structure, since the central area, tendinous, is more resistant. The position of the patient and the abdominal viscera at the moment of trauma will determine the location (right, left, bilateral or central) and the size of the defect generated in the diaphragm (HUNT; JOHNSON, 2018; WORTH; MACHON, 2005). Discontinuities on the right side of the diaphragm of dogs and cats are often observed (BESALTI et al., 2011; OZER et al., 2007). However, in this report, the rupture was visualized on the left side, like that described in an orange-spined-hairy-dwarf-porcupine specimen (Sphiggurus villosus) by MOTTA et al. (2012).
The hernial content may consist of one or more abdominal organs, including the liver, followed by the stomach, omentum, small intestine, and spleen (BESALTI et al., 2011; OZER et al., 2007). In the reported case, these same organs were projected in the thoracic cavity, except for the spleen. Although they were not observed in this case, other organs such as the kidneys, large intestine, pancreas and gallbladder, may also undergo displacement to the thorax (COPAT et al., 2017; GIBSON; BRISSON; SEARS et al., 2005; WORTH; MACHON, 2005).

Similar to other studies, the reported patient presented clinical respiratory manifestations, such as intense dyspnea with restrictive and paradoxical breathing pattern. In diaphragmatic hernia, respiratory dysfunction occurs due to lung expansion restricted by protruded abdominal organs, and due to loss of mechanical function of the diaphragm. Cardiovascular function is also impaired as a result of compression exerted on the caudal vena cava and reduction of venous return to the heart (HUNT; JOHNSON, 2018; WORTH; MACHON, 2005). The association of these events may be aggravated if there is pulmonary contusion, pneumothorax, and rib fracture, as presented by the patient in this report (BESALTI et al., 2011; OZER et al., 2007).

The diagnosis of diaphragmatic hernia is based on a simple radiographic examination of the abdomen and chest, in which the changes observed include the loss of the diaphragmatic line and cardiac silhouette, and the presence of abdominal organs in the thoracic cavity (HYUN, 2004). However, some patients may not present radiographic evidence of this condition, as in cases where herniation of small portions of abdominal organs occurs (WORTH; MACHON, 2005). In the reported patient, no changes were found in the simple chest and abdomen radiographic study. For this reason, a contrast-gastrointestinal ultrasonographic and radiographic study was performed to confirm the diagnosis of diaphragmatic hernia. Inconclusive cases such as this can also be diagnosed by peritoneography, laparoscopy, thoracoscopy, computed tomography and T-FAST (Thoracic Focused Assement with Sonography for Trauma) (BECK et al., 2004; LISCIANDRO, 2014; COPAT et al., 2017).

The anesthesia of patients with diaphragmatic hernia is challenging, given the cardiorespiratory impairment, which can be aggravated by stress, poor positioning on the operating table, and depressant effects of some drugs (WILSON, 1992). Pre-oxygenation, volume replacement, blood transfusion, and thoracic drainage are essential for patient stabilization (WORTH; MACHON, 2005). The anesthetic agents used in this report are indicated by Wilson (1992) and were used by other authors, with minimal alteration to the general state of the patient (BESALTI et al., 2011; LEGALLET; MANKIN; SELMIC, 2017; OZER et al., 2007)

The definitive treatment of diaphragmatic hernia is the surgical correction of the diaphragm, and the median laparotomy approach is widely used in $\operatorname{dog}$ and cat medicine 
(BESALTI et al., 2011; HUNT; JOHNSON, 2018; WORTH; MACHON, 2005). In this report, access to the diaphragm through median ventral laparotomy provided satisfactory exposure of the diaphragmatic defect and repositioning of the abdominal organs, which led to the discarding of the need for association of other surgical approaches.

Most diaphragmatic ruptures are large enough for herniorrhaphy, which should be performed in a simple, continuous, or interrupted pattern, with non-absorbable or absorbable material (HUNT; JOHNSON, 2018;). In this case, the defect was completely repaired with a simple suture pattern interrupted with non-absorbable material; thus, the use of muscle grafts or synthetic implants was not necessary.

The first 24 hours after the surgical procedure are critical; therefore, it is recommended to continue oxygen supplementation, analgesia and performance of periodic pleural drainage, if necessary, in order to avoid pneumothorax and pleural effusions, which are the main causes of death in dogs (GIBSON; BRISSON; SEARS et al., 2005). After this period, the prognosis of this condition is considered good and greater chances of survival of the patients are associated, mainly, with the advancement of anesthetic protocols and intensive care during the peri/postanesthetic periods (LEGALLET; MANKIN; SELMIC, 2017; WORTH; MACHON, 2005). In this report, despite the early removal of the thoracic drain by the patient, no complications were observed and, at the end of 14 days after surgery, the clinical condition was stabilized and without signs of recurrence.

\section{CONCLUSION}

It is concluded that traumatic diaphragmatic hernia is an important condition that can affect wild animals. The clinical manifestations and alterations found in complementary examinations are like those found in small animal medicine. The contrasted radiographic examination was fundamental for the precise diagnosis of this condition and for the choice of the appropriate therapy. The technique of herniorrhaphy, via access by median laparotomy, which until now has not had its use reported for Didelphis albiventris specimens, has proven effective to preserve the life of the patient in this study.

\section{REFERENCES}

BECK, C. A. C. et al. Laparoscopia nas hérnias diafragmáticas: estudo experimental em cães. Ciência Rural, v. 34, n. 6, p.1849-1855, 2004.

BESALTI, O. et al. A retrospective study on traumatic diaphragmatic hernias in cats. Ankara Üniversity Veteriner Fakültesi Dergisi, v. 58, p. 175-179, 2011.

COPAT, B. et al. Herniorrafia diafragmática videoassistida em gato: relato de caso. Arquivo Brasileiro de Medicina Veterinária e Zootecnia, v. 69, n. 4, p. 883-888, 2017.

GIBSON, T.W. G.; BRISSON, B. A.; SEARS, W. Perioperative survival rates after surgery for diaphragmatic hernia in dogs and cats: 92 cases (1990-2002). Journal of the American Veterinary Medical Association, v. 227, n. 1, p. 105-109, 2005.

HARO, P. et al. Physiological basal parameters of free-ranging opossums (Didelphis virginiana) in the Yucatan Peninsula, Mexico. Journal of Zoo and Wildlife Medicine, v. 49, n. 2, p. 480-483, 2018.

HUNT, G. B.; JOHNSON, K. A. Diaphragmatic Hernias. In: TOBIAS, K. M.; JOHNSTON, S. A. Veterinary Surgery: Small Animal. 2. ed. St. Louis: Elsevier, 2018.

HYUN, C. Radiographic diagnosis of diaphragmatic hernia: review of 60 cases in dogs and cats. Jounal of Veterinary Science, v. 5 , ก. 2, p. 157-162, 2004.

LEGALLET, C.; MANKIN K. T.; SELMIC, L. E. Prognostic indicators for perioperative survival after diaphragmatic herniorrhaphy in cats and dogs: 96 cases (2001-2013). BMCVeterinary Research, v. 13, ก. 16, 2017.

LISCIANDRO, G. R. The Vet Blue Lung Scan. In: LISCIANDRO, G. R. Focused Ultrasound Techniques for the Small Animal Practitioner. Ames: Wiley Blackwell, 2014.

MOTTA, A. C. et al. Broncopneumonia abscedativa associada à hérnia diafragmática em ouriço-cacheiro (Sphiggurus villosus). Revista Acadêmica: Ciências Agrárias e Ambientais, v. 10, n. 4, p. 409-412, 2012.

OLIVEIRA M. L. et al. Estudo populacional de gambás, Didelphis albiventris (mammalia, didelphidae), em um pequeno fragmento florestal. Mastozoología Neotropical, v. 17, n. 1, p. 6l-165, 2010.

OZER, K. et al. Diaphragmatic hernia in cats: 44 Cases. Medycyna Wet, v. 63, n. 12, p. 1564-1567, 2007.

WILSON, D. V. Anesthesia for Patients with Diaphragmatic Hernia and Severe Dyspnea. Veterinary Clinics of North America: Small Animal Practice, v. 22, n. 2, p. 456-459, 1992.

WORTHA. J.; MACHON R. G. Herniação diafragmática traumática: fisiopatologia e tratamento. Compendium on Continuing Education for the Practicing Veterinarian, v. 27, n. 3, p. 78-190, 2005.

ZIMMERMANN, M. et al. Membranas de látex natural na herniorrafia diafragmática experimental em cães. Arquivo Brasileiro de Medicina Veterinária e Zootecnia, v. 60, n. 6, p. 1476-1483, 2008. 